全顎口内撮影法に比べてみると，装置よりの距離 100 cmの所で, 床上 $140 \mathrm{~cm}$ では Palomex で 1/11〜4/40, $\mathrm{Pa}$ nex では〜 $1 / 4$ と低く，朱上 $110 \mathrm{~cm}$ では Palomex で1, 1,12, Panex で1/3〜1/8を示し，また床上 $70 \mathrm{~cm}$ では Palomex で1/9〜1,28, Panex で1/4〜1,18 とそれぞれ少くない 值を示している. Palomex と Panex では, 構造上の 違いもあり，Panex は管電圧が高いことと，撮影時間 が約 2 倍であるととから散乱線量も $2 \sim 3$ 倍の值を示し た. パノラマ撮影の場合は, 全顎口内撮影法に比べ散乱 線量が少ないと報告されているように，我々の実験結果 でも, Palomex で1/9〜1/40, Panex で1/20と少ない值を 示した. このことは術者並びに患者に対する被曝量の軽 減の意味からも極めて有意であり，また撮影操作におい ても比較的簡便なため, 歯科臨床上多いに利用さるべき ものと考える.

\section{2. 咬筋の筋電図と咀噒面の関係について}

大曲統司明・O本田栄子 井上 功・原ケイ子（生理）

研究目的：再側咬笳の放電と咀礵面との関係を調べる 目的で本実験を行なった。

研究方法：上下顎の第一大曰霜と第二大臼崡に欠損が なく，金冠や大きな充填物を持たない，20才から44才ま での男女17名を被検者とした。

咀嚼面の測定は，亜鉛華ユージノール印象材をガーゼ の両面に塗布し，乙れを上下の大曰䨑部の咬合面にあ て，中心位で咬合させ，咬合面の印象を採得した。この 印象を引伸機でケント紙上に投影し，ガーゼ一枚の厚さ になった部分をトレースした.つぎにての部分を切り奴 き，重量を測定し，のち，面積に換算した。

筋電図は中心位のかみしめ，左側でのかみしめ，右側 でのかみしめを行なわせたとき，再側咬筋に発生する放 電を同時記録した．記録電極は口角部と耳下点を結ぶ線 上で咬筋の筋幅の中央に固定した，不関電極は鼻根部に あてた．電極は日本光電製のディスポーザブルの表面電 極を使用した。

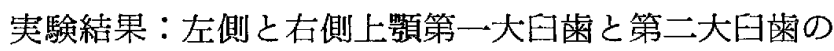
咀嚼面の最も狭いものは53.8mn，最も広いものは 124.6 m施であった. 左側と右側の咀嚼面の広さの差は最も小さ いもので $1.3 m$ ，最も広いものでは77.8mであった，両 側咬筋の放電活動に差異の認められる例は 12例であっ た. このうち，9例は咀嚼面の広い側と咬筋の放電活動 の大きい側が一致した．しかし，3例は放電活動の大き
い側と咀簿面の広い側とが一致しなかった１7例中 5 例 は放電活動に差異が喼められなかった。

結論：両側の上顎第一大曰雨と第二大曰䨑の咀嚼面の 広さを測定し, 両側咬筋の放電活動との関連について検 討した.

咀嚼面の広い側が咬筇の放電活動も大きい例が，かな り多かった。

\section{3. 䓵下について}

\section{○中村修一・濤崎亘三郎・中原敏（生理）}

研究目的：滺下運動の第一相は随意運動であると同時 に反射的な運動でもある. 今回我々は, 舆下運動が起て るためにはなならかの口腔内よりの情報があるのでは ないかと考元, 咀嚼開始より嚾下までの咀嚼運動を筋電 図で観察する一方，乙れらの被検者の咀嚼能力を測定し 比較検討した。

研究方法：実験は正常咬合を有する19才から30才まで の22名を対象として行なった。乙れらの被検者に，ピー ナッ $5 g$ をかませ，咀嚼時の筋電図を記録した。なお筋 電図は，左右の咬筋，側頭筋より記録した。また記録電 極は表面電極を使用し，双極誘導した，咀嚼能力の計測 は横田らの方法に従い，人工試料を用いて計測した。

研究成績：ピーナッ $5 \mathrm{~g}$ の燕下までの咀嚼回数は, 平 均44.9標準偏差 \pm 10.3 , 咀嚼時間は平均 $31.9 \mathrm{Sec}$ 標準偏 差土 7.5Sec であった. 咀嚼回数と咀嚁時間との関係に は相関が認められ，相関係数 $\mathrm{r}=0.79$ であった. 1 回当 りの平均咀嚼時間は， $0.77 \mathrm{Sec}$ 標準偏差 $\pm 0.12 \mathrm{Sec}$ であ った.つぎに咀嚼までの閉口運動時間の合計と開口運動 時間の合計との関係には相関が認められ，相関係数 $\mathbf{r}$ $=0.73$ であった. 咀㘉能力は平均 $4.6 \mathrm{~kg} \mathrm{~cm} / \mathrm{g}$ で標準偏差 \pm 0.6 であった，藇下までの阻㘉回数之咀嚼能力との相 関は $\mathrm{r}=0.13$ であった.

結論：正常咬合を有する19才から30才までの被検者 22 名にピーナッ $5 g$ を与光, 晿下闇に達するまでの阻嚼運 動のEMGを記録観察した。つぎに咀嚼能力を各人につ いて，計測しつぎの結論をえた１）正常咬合者におい て嚾下に到るまでの咀嚼回数に相当の個人差を認めた。

2) 咀嚼回数之咀嚼能力との相関は認められなかった.

\section{4. ラット歯牙神経の発生学的研究}

○村上俊明 $\cdot$ 上野正康（口病）

過去の文献をみても歯の発生過程において神経線維は 